\title{
Adsorptive Removal of Dyes onto Cost Effective Biomaterials - A Review
}

\author{
Mary Jency $\mathbf{I}^{1}$, Gowrisankar $\mathbf{L}^{2}$, Krishnaveni $\mathbf{J}^{3 *}$, Renugadevi. $\mathbf{N}^{4}$ \\ ${ }^{1,2}$ Department of Chemistry, Karpagam College of Engineering, Coimbatore. Tamilnadu, India \\ ${ }^{3}$ Department of Chemistry, Suguna college of Engineering, Coimbatore. Tamilnadu, India \\ ${ }^{4}$ Department of Chemistry, Faculty of Science, Avinashilingham University, Coimbatore, Tamilnadu, India \\ Received: 25/06/2020 \\ Accepted: 13/10/2020 \\ Published: 20/03/2021
}

\begin{abstract}
A higher percentage of dyes from the industrial waste water are being released into aquatic ecosystems and polluted the natural ecosystem. An abundance of technologies available for removal of Dyes from the industrial waste water are expensive and ineffective. Many of these processes are economically not viable for small and medium scale industries due to large scale applications.Recent Investigational researches have proved that the successful elimination of dyes is obtained using numerous economically available nonconventional adsorbents also. Several experimental investigations on adsorption provedthattremendous treatment for dye removal and can be obtained using cheaply available non-conventional adsorbent. This review is mainly focused to the systematic study on utilizing low cost absorbent of dye removal from the effluents discharged from the industries. The data on economically cheap adsorbents and its properties for removing dyes resulted from the recent literature survey are summarized. Therefore, this review provides the various methods to treat the wastewater using low-price natural sources of adsorption materials, non-viable biomaterials.
\end{abstract}

Keywords: Classification of dye, Dye removal method, Adsorption, Industrial effluents, Biomass

\section{Introduction}

With growing technology and science, global has reached to a very fresh horizon. Dyes are highly objectionable pollutant leads to the issues such as sensitization of skin, eye and skin irritation and dyes are highly carcinogenic nature. Due to demand on economical source and space to install the facilities of on-site treatment, the major donors of industrial effluents are the enterprises of small and medium size. The essential and environment challenge in recent years are the wastewater dye removal process that should be cheap and efficient. Most of the industries used to treat the effluent before discharging them to the environment, they are recycling off-site and diluted to decrease the toxicity that have proven to be highly economic and ultimately unsustainable. Therefore, it is required to create an effective process that can efficiently remove color is now at an utmost priority, one out of them is adsorption using activated carbon. Many investigations on adsorption reveal that the process is effective for the colour removal from the dye effluents. Commercial activated charcoal (carbon) is found to be effective but expensive one. Thus, it is necessary to find an adsorbent which is abundant, cheap and also effective (63).

\section{Classification of Dye}

Based on the application mode, dyes are generally classified according to their structure. It is virtue to point that the principal system adopted to classify by its applications are Color Index (C.I) with its five-digit number and hue (51) shown in Table 1.

\subsubsection{Dye Removal Methods}

Selection of dye, uses and its application were not given great importance with regard to environmental impact before few decades earlier. Many information is available in the last few years regarding the effects of using the dyestuff in the environment. Control measures to treat the dye wastewater are done by government, users and the dye manufacturers. According to physical, chemical and biological process some treatment methods can be done i.e., shown in Table 2.

\subsubsection{Adsorption Process}

Generally, the process of adsorption is used for removing the colour and for the treatment of wastewater (10). Among all the methods available for removal of dye from industrial waste waters, the adsorption process only proved as possible method for removal of dye in waste water treatment. Hippocrates and Pliny the Elder studied the carbon adsorption of porous for medicinal purpose and earlier the adsorption on carbon method was studied in an ancient Egyptian Papyrus. The quantity of absorbate that gather on the outer layer of the absorbent that commonly contains high surface area and porous structure are the significant properties to be noticed. The important point to consider is that the time required for achieving adsorption equilibrium should be as short as possible; therefore it is used for removing the dye from waste in shorter time. The physical and chemical methods are the two basic activation methods that are known to be the oldest for activated carbon adsorbent which is prepared from coal, lignite, wool and coconut shells. The formation of product is porous in nature along with a surface area ranges from $500 \mathrm{~m}^{2} / \mathrm{g}$ to $2000 \mathrm{~m}^{2} / \mathrm{g}$ which is large. As a result, many researchers attempted to develop an alternate 
cheap adsorbent and for controlling the pollution that may replace the available commercial activated carbon by Adsorption process.

Table 1: Classification of Dyes

\begin{tabular}{|l|l|l|}
\hline Types & Solubility & Sources \\
\hline $\begin{array}{l}\text { Acid } \\
\text { Dyes }\end{array}$ & Soluble in water & $\begin{array}{l}\text { Ink jet printing, nylon, paper, } \\
\text { leather modified acrylic, wool, } \\
\text { food and cosmetics. }\end{array}$ \\
\hline $\begin{array}{l}\text { Basic } \\
\text { Dyes }\end{array}$ & Soluble in water & $\begin{array}{l}\text { Polyesters that modified, } \\
\text { medicine, nylons, polyethylene } \\
\text { terephthalate of dyeing cation, } \\
\text { paper and polyacrylonitrile. }\end{array}$ \\
\hline $\begin{array}{l}\text { Vat Dyes } \\
\text { Solvent } \\
\text { Dyes }\end{array}$ & $\begin{array}{l}\text { Insoluble in } \\
\text { water }\end{array}$ & $\begin{array}{l}\text { Cellulosic fibers, cotton, rayon } \\
\text { and wool. }\end{array}$ \\
\hline $\begin{array}{l}\text { Direct } \\
\text { Dyes }\end{array}$ & $\begin{array}{l}\text { Anionic dyes } \\
\text { which are } \\
\text { soluble in water }\end{array}$ & $\begin{array}{l}\text { Gasoline, waxes, oils, petrol and } \\
\text { lubricants. }\end{array}$ \\
\hline $\begin{array}{l}\text { Rylon, cotton dyeing, rayon, } \\
\text { leather and paper. }\end{array}$ \\
\hline $\begin{array}{l}\text { Disperse } \\
\text { Dyes }\end{array}$ & $\begin{array}{l}\text { Water-insoluble } \\
\text { non-ionic dyes }\end{array}$ & $\begin{array}{l}\text { Nylon, polyester, cellulose and } \\
\text { fiber acrylics. }\end{array}$ \\
\hline
\end{tabular}

\subsection{Low cost Adsorbents}

Physical methods like ion exchange and reverse osmosis were used for the removal of dyes form the industrial waste water. However, due to their high capital and operational costs, these methods restrict the use in large scale level in the industries. Among all the process that are available for treating the effluents, adsorption method shows possible treatment to remove the organic pollutant from industrial wastewater.
Therefore, adsorption processes are more advantageous over the available process due to its low capital cost, operation cost and also for simpler design. Absorbents which are naturally available, wastes and by products obtained from industries and synthetic products which are economical are called low price adsorbents. Researchers suggest and adopt this concept according to the various discussions on forming, using and applying the low-price adsorbents. The low-price adsorbents studied on the based on their availability as follows: (a) natural available materials; (b) industrial/ Domestic/ Agricultural wastes and by-products; and (c) synthesized products (biomass).

\subsubsection{Naturally available Materials}

The naturally available materials are used as cost low adsorbents which exist in natural environment and are used as such or with small treatment. The bark of the Eucalyptus can be used as an absorbent without any minor treatment for dye removal. Wood is used for the acid removal and basic dye removal to overcome the economic drawback of activated charcoal. Coal which exists naturally is used for removing both acid and basic dye. For the removal of Triazo direct dye, coalbased adsorbents like lignite coal, bituminous coal and char fines have been used. Peat is another adsorbent which is naturally available and used for the various pollutants and dyes by most of the researchers. Ramakrishna and Viraraghavan (46, 48 ) identified the potential of adsorbent such as peat, bentonite clay, fly ash and slag for removing the acid, base and disperse dye. Of many naturally available materials, clay occupies a very good place in being cheap, abundant and possessing excellent property of adsorption. Sepiolite were used for the removing the reactive blue 221 .

Table 2: Methods of Dye Removal

\begin{tabular}{|c|c|c|c|}
\hline \\
\hline Methods & Types & Drawback & Advantages \\
\hline $\begin{array}{l}\text { Physical } \\
\text { Treatment }\end{array}$ & $\begin{array}{l}\text { Sedimentation process, Reverse } \\
\text { Osmosis, microfiltration, } \\
\text { ultrafiltration, nanofiltration }\end{array}$ & $\begin{array}{l}\text { Life span of membrane is short, membrane } \\
\text { is costly, energy consumption is high and } \\
\text { high pressure on working (61). }\end{array}$ & $\begin{array}{l}\text { Economically attractive. Good } \\
\text { removal efficiency Cost } \\
\text { intensive regeneration process, } \\
\text { Regeneration with low loss of } \\
\text { adsorbents, Good sorption for } \\
\text { specific colourant, Effective } \\
\text { removal for a wide range of } \\
\text { colourants at low volumes (6). }\end{array}$ \\
\hline $\begin{array}{l}\text { Chemical } \\
\text { Treatment }\end{array}$ & $\begin{array}{l}\text { Coagulation, Flocculation Process, } \\
\text { Oxidation process }\left(\mathrm{H}_{2} \mathrm{O}_{2}, \mathrm{Cl} \text {, Fenton's }\right. \\
\left.\text { reagent, } \mathrm{KMnO}_{4} \text { and } \mathrm{O}_{3}\right) \text {, Ozonation } \\
\text { process, Photo catalysis, Advanced } \\
\text { Oxidation Process. }\end{array}$ & $\begin{array}{l}\text { The } \mathrm{pH} \text { range less than } 3.5 \text { shows sludge } \\
\text { formation, long reaction time }(2,22,33 \text {, } \\
49,60,68) \text {. }\end{array}$ & $\begin{array}{l}\text { Effective for both soluble and } \\
\text { insoluble colourants, Capable } \\
\text { of decolourizing wide variety } \\
\text { of wastes, Short detention time } \\
\text { and low capital costs, Good } \\
\text { removal efficiencies }(6,59 \text {, } \\
67) \text {. }\end{array}$ \\
\hline $\begin{array}{l}\text { Biological } \\
\text { Treatment }\end{array}$ & $\begin{array}{l}\text { Conditions like Anaerobic, Aerobic } \\
\text { or both anaerobic-aerobic } \\
\text { Bacteria and fungi such as } \\
\text { Phanerochaetechrysosporium, } \\
\text { Escherichia coli, Pseudomonas } \\
\text { aerogenosia, Bacillus species, and } \\
\text { various microorganisms of } \\
\text { Klebsiellaspecies. }\end{array}$ & $\begin{array}{l}\text { Large landscape is required, longer times, } \\
\text { cost-effective, biodegradability is low, } \\
\text { flexibility is low in design and operation } \\
(4,11,13,44,50,52)\end{array}$ & $\begin{array}{l}\text { Colour removal is facilitated } \\
\text { along with COD removal, } \\
\text { Resistant to wide variety of } \\
\text { complex colourants. Bio gas } \\
\text { produced is used for steam } \\
\text { generation, Good removal } \\
\text { efficiency for low volumes and } \\
\text { concentrations. Very effective } \\
\text { for specific colourant removal } \\
(6,59,67) \text {. }\end{array}$ \\
\hline
\end{tabular}


Besides these, montmorillonite, kaolinite, smectites, diatomite and alunite clays are also used as adsorbent for dye removal. $\mathrm{TiO}_{2}$ nanoparticles are used for the removal of methyl violet and Zeolite is the adsorbent which is microporous in nature utilized mainly for eliminating pollutants and dyes $(39,42)$. Beach sand coated with polyaniline were used as an efficient green adsorbent for removing dye from aqueous solution (7).It has proved that beach sand has extremely costeffective substrate for coating with polyaniline in order to be used as efficient adsorbent for dye removal from aqueous solutions.

The removal of the anionic dyes using natural sepiolite and bentonite are related with the activated carbon was studied (17). A surfactant removal of $90 \%$ was achieved in within 15 min due to the more affinity between adsorbent and surfactant. Natural bentonite activated with $0.5 \mathrm{M} \mathrm{H} 2 \mathrm{SO} 4$ was proved that the most successful adsorbent for ethoxylatednonylphenol.

\subsubsection{Industrial/ Domestic/Agricultural wastes and its by- Products}

Besides many naturally available materials, numerous wastes from agricultural and its by-products were explored to be an adsorbent for eliminating the pollutants by a bunch of workers. Sawdust, almond shells, walnut and poplar has been studied for removing the acid red 183 and green 25 dyes from the aqueous solution. Some cheap adsorbents such as walnut sawdust, pitch pine, cherry, oak and ground hazelnut materials were carried out to remove the Acid Blue and Methylene Blue dyes from the effluents (19). To remove basic and direct dyes, Sunflower stalks and cotton stalk were studied as adsorbent (15). Subha and Namasivayam, 2009, studied on coir pith which is an agriculture residue as a good adsorbent for adsorptionof Rhodamine B and Acid Violet dyes that proved. The adsorption capacity was found to be $2.6 \mathrm{mg} / \mathrm{g}$ of acid violet dyes (64). An attempt of removing industrial dye using dried green seaweeds was carried out (47). The maximum removal percentage and efficiency was $100 \mathrm{mg}$ fine biomass of green seaweeds $100 \mathrm{mg} / \mathrm{L}$ dye solution. Another appealing agriculture waste is the sawdust, mainly used for removing heavy metals and dyes (38). The study was also carried out with timber sawdust for the methyl violet dye biosorption and dye adsorption dependency by other workers (40) the chemically tailored adsorbent behaves proficiently in a extensive $\mathrm{pH}$ range throughout the consistent and quick sorption process.

The wastes and the by-products which are formed from steel, sugar, metal, thermal power planta and industrial fertilizer has been used as an adsorbent. From the bamboo pulp mill by-product spherical sulphonic lignin was prepared and Lignin was prepared from the paper mills discharge waste and by-product reviewed $(24,25)$. They also highlighted the utilization of Lignin adsorbent and its effective removalperformance and recovery of cationic dyes.

Coal based thermal power plant discharges high amount of fly ash and by-product materials. Fly ash as a cheap adsorbent were studied to remove cationic dye such as crystal violet and rosaniline hydrochloride. Dye removal such as acid yellow, disperse blue and direct yellowcan be done utilizing the fly ash adsorbent (5). By-products and wastes of steel plants discharges wastes and by-products such as blast furnaces slag, sludge and dusts wasstudied for the dye removal. Different dye removal like disperse red and acid red was achieved by fly ash adsorbent compare with other three adsorbents like peat, bentonite clay, and steel plant slag were suggested by other workers $(31,46)$.

Rice mills contains waste residues of rice husk ash, were used as an adsorbent for removing the dye of acidic in nature.
The possibility of using palm oil ash as a low-price adsorbent for the successfully removed the Two commercial dyes i.e. disperse blue and disperse red dyes (26). Attempt has been made to utilize the boiler bottom ash, saw dust ash, rice husk ash and wood coal with impregnation of an adsorbent for the removing the dye of basic nature (58). Shale oil ash was used as an adsorbent for the removal of dyes. Red mud, a by-product of aluminium industry has been investigated (37) for the removal of various dyes such as fast green, rhodamine B, methylene blue, congo red and also by diatomite. Another productive investigation was also done with the various basic dyes on process of adsorption and also onto Microporous activated carbon prepared from Euphorbia antiquorum L was impregnated with polyvinyl alcohol $(62,69)$.

During the combustion of liquid fuel in fertilizer plants, carbon slurry waste is generated and it has been transformed into activated carbon which is inexpensive. Generally, Sewage sludge is used to develop the material which is carbonaceous with the help of chemical activation. This material was utilized to remove dyes and phenol along with the wastes of blast furnaces slag, sludge and dust from the steel industries. To control the environment impact and to improve the low- price concept, an attempt was made to eliminate the dyes such as Methylene Orange and Methyl Blue by alginate beads that has activated carbon and carbon nanotubes(55). They showed the better results in The dye removal using $40 \mathrm{~g} \mathrm{~L}-1$ of CNTs was above $90 \%$ and also the amount of dye adsorption improved with increasing the initial concentration of the dye, CNTs dosage, and temperature.

Many materials like polymer materials, bottom ash, waste tyre rubber, de-oiled soya (34), double layered hydroxides, pyrite, black tea leaves and artificial iron sulphide, impregnated alum activated alumina, sorel's cement, rosacanina and calcined alunite seeds was studied as an adsorbent and proved as a effective removal efficiency percentage onto to the dyes. Utilization of waste peels of potato and activated orange (35), husk of potato (43), peels of mandarin and yellow passion fruit, Brazilian pine fruit shell, coffee bean, babassu, cupuassu related to cocoa, tree leaves, wood shavings (12), powders of different plant leaves (57) were investigated and showed the better results in efficiency of dye removal percentage in different $\mathrm{pH}$ range and high removal dye at $333 \mathrm{~K}$. The powder of orange peel $(18,29)$ was also used as an adsorbent and proved to be cheap and economical. Adsorbent like Mehagoni leaf and Neem is used for dye removal from the effluents discharged in textiles $(9,56)$. The efficiency for Neem leaf was found Blue BFG 50.5\%, Orange MERL 66.02\%, Red EV8V5(dye) $57 \%$, and for Mahagoni leaf Red EV8V5(dye) $77 \%$, Blue BFG $67.77 \%$, Orange MERL 60\%, respectively.

The adsorption of metals by different materials namely used tyres carbon, phosphate treated sawdust, olive cake/stone and pine needles, moss, risk husk carbon, cactus, maize cob, sphagnum moss peat, sugar beet pulp, cane bagasse, cow dung carbon, waste slurry, rice straw, quaternised wood, carbon slurry and hen feathers. Activated groundnut husk carbon, husk of coconut, ground nut shell, coconut shell, leaf mould, palm pressed fibers, wood and coconut juice carbon and coconut fiber $(16,23,32)$. From the above investigations proved that Activated Rice Husk, at $500 \mathrm{mg} / \mathrm{L}$ the highest of $62 \%, 68 \%$ and $65 \%$ elimination of $\mathrm{Zn}$ (II), $\mathrm{Cu}(\mathrm{II})$ and $\mathrm{Cr}(\mathrm{VI})$ were obtained respectively, but in Activated Coconut Fiber, at $500 \mathrm{mg} / \mathrm{L}$ the greatest of $64 \%, 67 \%$ and $72 \%$ removal of $\mathrm{Zn}(\mathrm{II}), \mathrm{Cu}(\mathrm{II})$ and $\mathrm{Cr}(\mathrm{VI})$ were obtained respectively.

Orange peel is used for the removing acid violet dye from aqueous solution and resulted in the maximum removal of $87 \%$ was proved at $\mathrm{pH} 2.0$ for an adsorbent dose of $60 \mathrm{~g} / 50 \mathrm{ml}$ of 1 
$\mathrm{g} / \mathrm{L}$ dye concentration (45). Banana pith is utilized for the process of adsorption of basic violet dyes from the waste water and Bagasse pith is used to eliminate the dyes which are acidic and basic nature. Another adsorbent such as husks of barley, corncobs and wheat straw was used for the adsorption of Cibacron Red, Blue and Yellow and Remazol Red, Black and palm fruit bunch was explored for the adsorption method to remove the Basic Red, Basic Yellow and Basic Blueby Robinson et al., 2001. Agricultural waste rice straw as adsorbent was employed to remove Malachite green (30), it was effectively removed more than $87 \%$ at concentration of 5 $\mathrm{g} / \mathrm{L}$ and at $\mathrm{pH} 8$.

\subsubsection{Biomass as an Adsorbent}

Microorganisms such as Bacteria, Fungi and Algae have great potential for degradation of dyes and has tendency to absorb the dyes from industrial effluents and also from aqueous solution. Many live microbial organisms namely Yeast, Fungi, Algae and Bacteria were investigated to confer the capability to uptake massive amount of dyes and heavy metals. Biomass is abundant and available at low cost that drives huge attraction in dye wastewater treatment. From Water Hyacinth having dry roots and are non-living, biomass can be produced as an adsorbent for removing dyes. Hydrillaverticillata has been reported as an absorbent for the elimination of Basic dye, Basic Violet and Methylene Blue (53). This Hydrillaverticillata plant was exposed to different dye concentrations under the hydroponic culture medium. The plant growth was normal at low concentration of dye and found to greater dye removal efficiency. The rate of removal efficiency decreased with increase in dye concentration. Studies like Langmuir and Freundlich isotherm, SEM, FTIR data were found to fit well. The investigation concluded that $\mathrm{H}$. Verticillate can be used as biosorption for waste water effluent management.

A massive potential and physicochemical property were identified in biomass adsorbent. By Fu and ViraRaghavan(21) investigation on biosorption using Aspergillusniger fungus from the discharged wastewater of textile industry by using Spirogyra species, a fresh water green algae removes dyes such as Congo Red, Disperse Red, Basic Blue 9 \& Acid Blue 29. The different functional groups present in the biosorbents are capable of biodegrading and biosorbing the dye from the wastewater and becomes more selective. Alternative to old treatment, biosorbent emerges as a best one on various research studies. Biomasses of Algae and fungi shows the excellent capability to discoloration (21). Using industrial fermentation processes, fungal biomass can be obtained economically for the adsorption of dyes and also which is a non-pathogenic material to human and animals. Spirogyra majuscule has high capability for binary uptake of dyes from the aqueous solution and this species has huge potential and could be very effective for the treatment of textile wastewater in industrial scale. The species could be a natural adsorbent without high cost. All these fungal biomasses can be used in the treatment dye contaminated effluent (1). Fomitopsisfeei and Spirogyra majuscula are the low-price fungal biomasses, which have been used as adsorbents for removing dyes $(1,14,27,65)$. The most promising biosorbent was identified to be Algae due to its abundance in salt water and fresh water. The potential of Algae biosorption is widely used because of their excellent binding affinity, huge surface area and the properties of cell wall contains functional groups of carboxylates, amino, hydroxyl and phosphate. This property is responsible for removal of dye. Spirogyra rhizopus may have the property of accumulating the dyes on the outer surface of Algal Biopolymers (41). The kinetic and equilibrium studies of biosorption were carried out on Spirogyra Rhizopus. The monolayeradsorption capacity of S. rhizopus was found to be 1356.6 for $\mathrm{AB} 290$ and $367.0 \mathrm{mg} / \mathrm{g}$ for AB 324 dyes. The biosorption data of AB 290 and AB 324 dye best fits with Koble-Corrigan and the Redlich-Peterson models. The thermodynamic parameters such as entropy, enthalpy and free energy change shows reversible and exothermic nature of the biosorption of the dyes by Spirogyra Rhizopus (41).

Algae such as Oscillatorialimosaand Nostoc commune are used for phycoremediation (8). This investigation showed that both algal species are effective for the degradation of several nutrients, chlorides and Electrical conductance from the wastewater. On all the selected algae Oscillatoriahasbest potential and act better for the large-scale treatment. Both the species have good performance for nitrogen fixation and the biomass produces act as bioresource for cultivation of paddy. Phycoremoval of nutrients, chlorides etc was found to be in lower concentration of wastewater and can be a sustainable method for wastewater treatment.

Recent studies showed that among all the unicellular algae species, heterogeneous species (Microsporaspecies, Rhizocloniumspecies, Diatoms, Lyngbyaspecies and Dinoflagellates) of fresh water algae and Chlamydomonasreinhardtii has added huge interest in the treatment of dye pollutant in aqueous solution (20). The result of this investigation reveals the process of metal ion binding is due to the biosorption. The Chlamydomonasreinhardtii best fit for removing copper and lead (II) ions from the aqueous solution. The conditions like medium, $\mathrm{pH}$, biomass preparation, metal - ion and biomass concentration have greater effect on copper and lead uptake. Regularizing these conditions increased the affinity of algal cells for the metals. The species are found to be efficient and economic biomaterials for removing the heavy metals from metal - contaminated wastewater (20). Marine green algae, Ulva lactuca and Sargassum are relatively large in surface area used for the removal of dye. Biosorption experiments were carried out for the removal of Methylene Blue onto dried Enteromorpha, Mediterranean green alga, onto Posidoniaoceanicafibers, a marine lignocellulosic biomass $(38,66)$. The experimental data shows a chemisorption process. The P. Oceanicafibres indicates that the experimented Mediterranean biomass, revealed a high biosorption towards basic dye (36). Natural biosorbentulvalactuca and sargassum species reveals a potential adsorption capacity rather than commercial adsorbent alumina. This Biosorbent shows $96 \%$ removal. All these were concluded by the adsorption models and shows spontaneous behavior (66). Mousavi et al., were investigated for the removal of $\mathrm{Pb}$ (II) ion in the aqueous solution by using the KombuchaScoby and $\mathrm{GO} / \mathrm{Fe}_{3} \mathrm{O}_{4}$ adsorbent (36). The maximum adsorption efficiencies for $\mathrm{GO} / \mathrm{Fe}_{3} \mathrm{O}_{4}$ and KombuchaScoby were found to be 98.08 and $99.73 \%$.

Although Biosorption\& Biomass acts as an excellent process replacing the non-renewable method for removing the dyes, there is only limited information available on the interactions and more studies are needed to confirm the interactions $(3,50,54)$. To change the biosorption process economical wise, it is necessary to regenerate the spent adsorbent in multiple sorption cycles. Several methods are investigated in the literature about the regeneration of organic pollutant loaded biomass. But detailed study is needed on spent biosorbent regeneration (3).

\section{Conclusion}

The review article highlighted the different methods that are usingthe easily available and cheap adsorbents for removal 
of dyes from the effluents.It is also identifiedthat many researchers use adsorption method to remove the organic and inorganic contaminants from the industrial effluents. Nonviable biomaterials are found to be effective, easier and have the capability to remove the color excellently. It is reviewed that the research on biomaterials reveals that they emerge to be a promising alternative to conventional treatment system. It's evidently proved that adsorption method hasmany natural biomaterials are available for removal of dyes from effluents. Many of these natural bio materials have excellent potentials for the dye removal from the effluents.

\section{Ethical issue}

Authors are aware of, and comply with, best practice in publication ethics specifically with regard to authorship (avoidance of guest authorship), dual submission, manipulation of figures, competing interests and compliance with policies on research ethics. Authors adhere to publication requirements that submitted work is original and has not been published elsewhere in any language.

\section{Competing interests}

The authors declare that there is no conflict of interest that would prejudice the impartiality of this scientific work.

\section{Authors' contribution}

All authors of this study have a complete contribution for data collection, data analyses and manuscript writing.

\section{References}

[1] AbuzerÇelekli, Mehmet Yavuzatmaca, Hüseyin Bozkurt. Binary adsorption of reactive red 120 and yellow 81 on Spirogyra majuscula. Middle-East Journal of Scientific Research.2 (2013) 740-748.

[2] Aguedach A, Brosillon S, Morvan J, Lhadi EK. Photocatalytic degradation of azo-dyes reactive black 5 and reactive yellow 145 in water over a newly deposited titanium dioxide. Appl. Catal.B., 57 ( 2005) 55-62.

[3] Aksu Z. Application of biosorption for the removal of organic pollutants: A review. Process Biochem. 40 (2005) 997-1026.

[4] ALAhmed GK, Saud. Some aerobic bacterial degradation and decolorization of different azo dyes. Journal of Biology, Agriculture and Healthcare. 4 (2014) 72-81.

[5] Albanis TA, Hela DG, Sakellarides TM, DanisTG,Removal of dyes from aqueous solutions by adsorption on mixtures of fly ash and soil in Batch and Column Techniques. Global Nest: The Int. Journal. 2 (2000) 237 - 244.

[6] Anjaneyulu Y, Sreedhara Chary N, Samuel Suman Raj D. Decolourization of industrial effluents: available methods and emerging technologies - a review. Rev Environ Sci Bio/Technol, 2005, 4: p. 245-273.

[7] Ansari R, Mohammad-khah A, Nazmi M. Application of chemically modified beach sand as low-cost efficient adsorbent for dye removal. Current Chemistry Letters. 2 (2013) 215-223.

[8] Azarpira H, Behdarvand P, Dhumal K, Pondhe G. Potential use of cyanobacteria species in phycoremediation of municipal wastewater. International Journal of Biosciences. 4 (2014) 105111.

[9] AzharulArafath Md, Mobarak Hossain, Alam SS, RaihanSourav. Studies on adsorption efficiency and kinetics of dye removal from textile effluent using some natural bio-adsorbent. International Journal of Scientific Engineering and Technology. 2 (2013) 853856.

[10]Bansal R.C, Goyal M. Activated Carbon Adsorption. Taylor \& Francis Group. Boca Raton. 2005.

[11]Barragan B.E, Costa C, Carmen Marquez M. Biodegradation of azo dyes by bacteria inoculated on solid media. Dyes Pigments. 75 (2007)73-81.
[12] Cardoso NF, Lima EC, Pinto IS, Amavisca CV, Royer B, Pinto RB, Alencar WS, Pereira SFP. Application of Cupassu shell as biosorbent for the removal of textiles dyes from aqueous solution. Journal of Environmental Management. 92 (2011) 1237 - 1247

[13]Crini G. Non-conventional low-cost adsorbents for dye removal: a review. Bioresour. Technol. 97 (2006) 1061-1085.

[14]Demir G, Ozcan K, Tufekci N, Borat M. Decolorization of Remazol Yellow RR Gran by white rot fungus Phanerochaetechrysosporium. Journal of Environmental Biology. 28 (2007) $813-817$.

[15]Deng H, Lu J, Li G, Zhang G, Wang X. Adsorption of methylene blue on adsorbent materials produced from cotton stalk. Chemical Engineering Journal. 172 (2011) 326 - 334.

[16]Edwin Vasu A. Surface modification of activated carbon for enhancement of Nickel (II) adsorption. E - Journal of Chemistry. 5 (2008) $814-819$.

[17]Espantaleon AG, Nieto JA, Fernandez M, Marsal A. Use of activated clays in the removal of dyes and surfactants from tannery wastewater. Appl. Clay Sci. 24 (2003)105-110.

[18]Fahim Bin AbdurRahman, MaimunaAkter, Zainal Abedin M. Dyes removal from textile wastewater using orange peels. International Journal of Scientific and Technology Research. 2 (2013) 47-50.

[19]Ferrero F. Dye removal by low cost adsorbents: hazelnut shells in comparison with wood sawdust. J. Hazard. Mater. 142 (2007) 144152.

[20]Flouty R, Estephane G. Bioaccumulation and biosorption of copper and lead by a unicellular algae Chlamydomonasreinhardtii in single and binary metal systems: A comparative study. Journal of Environmental Management. 111(2012) 106 - 114.

[21]Fu YZ, Viraraghavan T. Fungal decolorization of dye wastewaters: a review. Bioresour. Technol. 79 (2001): 251-262.

[22] Ghorai TK, Biswas SK, Dalai S, Pramanik P. Photooxidation of different organic dyes using $\mathrm{Fe}$ (III)- doped $\mathrm{TiO}_{2}$ nanophotocatalys prepared by novel chemical method. Applied Surface Science. 254 (2008)7498 - 7504 .

[23] Gopalakrishnan, Jeyadoss T, Manivannan V. Biosorption of Zn (II), $\mathrm{Cu}$ (II) and $\mathrm{Cr}$ (IV) from textile dye effluent using activated coconut fiber. Indian Journal of Science and Technology. 2(2009) $1-4$.

[24]Gupta VK, Ali I. Chapter 2 - Water Treatment for inorganic Pollutants by Adsorption Technology. Environmental Water; Advances in Treatment, Remediation and Recycling. (2013) 29 91.

[25]Gupta VK, Suhas, Application of low-cost adsorbents for dye removal - A review.Journal of Environmental Management. 90 (2009) 2313-2342.

[26] Hasnain Isa M, Siew Lang L, Asaari FAH, Aziz HA, AzamRamli N, Dhas JPA. Low cost removal of disperse dyes from aqueous solution using palm ash. Dyes and Pigments. 74(2007) 446-453.

[27] HimaBinduNidadavolu SVSSSL, Krishna Gudikandula, Shiva Krishna Pabba, SingaraCharyaMaringanti. Decolorization of triphenyl methane dyes by Fomitopsisfeei. Natural Science. 5(2013) 30-35.

[28] Ho YS, McKay G.Sorption of dye from aqueous solution by peat. Chem.Eng. J. 70 (1998) 115-124.

[29] Indira Khatod. Removal of methylene blue dye from aqueous solutions by neem leaf and orange peel powder. International Journal of Chem Tech Research. 5(2013) 572-577.

[30] Jagdish Singh, Gagndeep Kaur. Freundlich, Langmuir adsorption isotherms and kinetics for the removal of malachite green from aqueous solutions using agricultural waste rice straw. International Journal of Environmental Sciences. 4(2013) 250-258

[31]Janos P, Buchtova H, Ryznarova M. Sorption of dyes from aqueous solutions onto fly ash. Water Res. 37(2003) 4938-4944.

[32] Kannan N, Vijayakumar A. Comparative study on the removal of Red Industrial dye using Groundnut shell and Coconut shell Carbon. Indian J. Environmental Protection.28 (2008) 1034 1040 .

[33] Konstantinou IK, Albanis TA. $\mathrm{TiO}_{2}$-assisted photocatalytic degradation of azo dyes in aqueous solution:kinetic and mechanistic investigations-A review.Appl.Catal.B. 49 (2004)114. 
[34] Mittal A, Mittal J, Malviya A, Dipika Kaur, Gupta VK. Adsorption of hazardous dye crystal violet from wastewater by waste materials. Journal of Colloid and Interface Science. 343(2010) 463- 473.

[35] Monika, Drivjot, Amita. Adsorption of dyes from aqueous solution using Orange Peels: Kinetics and Equilibrium studies. Journal of Advanced Laboratory Research in Biology. (2012) 3:1.

[36] Mousavi S.M, Hashemi S.A, Amani A.M, Mojoudi F, Arjomand $\mathrm{O}$. $\mathrm{Pb}(\mathrm{II})$ removal from synthetic wastewater using KombuchaScoby and graphene oxide/Iron oxide. Physical Chemistry Research. 6 (2018) 759-771.

[37] Namasivayam C, Arasi D. Removal of Congo Red from wastewater by adsorption onto waste red mud. Chemosphere. 34(1997) 401-417.

[38]Ncibi MC, BorhaneMahjoub, MongiSeffen. Kinetic and equilibrium studies of methylene blue biosorption by Posidoniaoceanica(L.) fibres. Journal of Hazardous Materials B. 139 (2007) 280-285.

[39]Nezamzadeh - Ejhieh, Banan Z. Sunlight assisted photo decolourisation of crystal violet catalyzed by $\mathrm{CdS}$ nanoparticles embedded on Zeolites. Desalination, 284(2012) 157 - 166.

[40] Ofomaja AE. Ho YS. Effect of temperatures and $\mathrm{pH}$ on methyl violet biosorption by Mansonia wood sawdust. Bioresour. Technol. 99(2008) 5411-5417.

[41] Ozer A, GonulAkkaya, MeralTurabik. Biosorption of Acid Blue 290 (AB 290) and Acid Blue 324 (AB 324) dyes on Spirogyra rhizopus.Journal of Hazardous Materials, B. 135(2006) 355-364.

[42] Panneerselvam P, SathyaSelvaBala V, Thinakaran N, Baskaralingam P, Palanchamy M, Sivanesan S. Removal of Nickel (II) from aqueous solutions by adsorption with Modified ZSM - 5 Zeolites. E - Journal of Chemistry. 6(2009) 729 - 736.

[43]Pooja V Shrivastava. Study on Color Removal of Basic Dye by Potato Husk as an Adsorbent. Journal of Chemical, Biological and Physical Sciences. 2(2012) 597-600.

[44]Rai HS, Singh S, Cheema PPS, Bansal TK, Banerjee UC. Decolorization of triphenylmethane dye-bath effluent in an integrated two- stage anaerobic reactor Journal of Environmental Management. 83 (2007) 290 - 297.

[45] RajeshwariSivaraj, Namasivayam C, Kadirvelu K. Orange peel as an adsorbent in the removal of Acid Violet from aqueous solutions. Waste Management. 21 (2001) 2001.

[46] Ramakrishnan KR, Viraraghavan T. Dye removal using low cost adsorbents, Water Sci. Technol. 36(1997)189-196.

[47]RekhaDeokar, AnajaliSabale. Biosorption of methylene blue from aqueous solution onto green seaweeds. International Journal of Recent Scientific Research. 5(2014) 347-351.

[48]Renugadevi N, Rajalakshmi R, Subhashini S, Lalitha P, Malarvizhi T. Usefulness of activated carbon prepared from agro waste in the removal of dyes from aqueous solution. Indian.J. Environmental Protection. 29(2009) 250 - 254.

[49]Rishi Ananthashankar, Abdel Ghaly. Photocatalyticdecolourization of textile effluent containing reactive red 120 dye with $\mathrm{UV} / \mathrm{TIO}_{2}$, American Journal of Engineering and Applied Sciences. 6(2013) 252-262.

[50]Robinson T; Chandran B, Nigam P. Studies on the production of enzymes by white rot fungi for the decolurisation of textile dyes. Enzyme and Microb. Technol. 29(2001) 575 -579.

[51] Sabnis RW. Handbook of Biological Dyes and Stains. John Wiley \& Sons, Inc., Hoboken, New Jersey.2010.

[52] Sani R, Banerjee U. Decolorization of triphenylmethane dyes and textile and dye-stuff effluent by Kurthia sp. Enzyme and Microb. Technol. 24(1999) 433-437.

[53] Saranya G, Saravanan P, Dharmendira Kumar M, Renganthan S. Equilibrium uptake and bioaccumulation of Basic Violet 14 using submerged MacrophyteHydrillaverticillata. CLEAN - Soil, Air, Water, 39(1999) $283-288$.

[54] Sarwa P, Verma SK. Decolourization of orange G dye by microalgae AcutodesmusObliquusstrain PSV2 isolated from textile industrial site. International Journal of Applied sciences and Biotechnology. 1(2013) 247-252.

[55] Shahryari Z, AtaallahSoltaniGoharrizi, Mehdi Azadi. Experimental study of methylene blue adsorption from aqueous solutions onto carbon nano tubes. International Journal of Water Resources and Environmental Engineering. 2 (2010) 016-028.
[56] Sharma A, Bhattacharyya KG. Utilizaion of a biosorbent based on Azadirachtaindica (Neem) leaves for removal of water - soluble dyes. Indian Journal of Chemical Technology. 12(2005) 285 - 295.

[57] Sharmila S, Shashi Bala, Jeyanthi Rebecca L. Adsorption of Rhodamine B on different plant leaf powder. Journal of Chemical and Pharmaceutical Research. 5(2013) 144-147.

[58] Shri Ram Chaurasi, Shashikant. Removal of Basic Dye from aqueous solution using natural adsorbents: Kinetic studies. Indian J. Environmental Protection. 27 (2007) 782 - 788.

[59] Sivarajasekar N, BaskarRajoo. Agriculture waste biomass valorisation for cationic dyes sequestration: A concise review. Journal of Chemical and Pharmaceutical Research, 2015, (79): p. 737-748.

[60] Soares OSGP, Orfao JJM, Portela D, Vieira A, Pereira MFR Ozonation of textile effluents and dye solutions under continuous operation: Influence of operating parameters. J. Hazard. Mater. 137 (2006)1664-1673.

[61] Sostar-Turk S, Simonic M, Petrinic I. Wastewater treatment after reactive printing. Dyes Pigments.2005, 64:147-152.

[62] Srinivasan P,SivakumarP,Raja S. PVA supported microporous adsorbents for the remediation of dye house wastewater.Journal of Scientific and Ind. Research. 72(2013)193-197.

[63] Srinivasan A, Viraraghavan T. Decolorization of dye wastewaters by biosorbents:A review. 91(2010)1915 - 1929.

[64] Subha R, Namasivayam C. Zinc chloride activated coir pith as lowcost adsorbent for the removal of 2,4 - dichlorophenol: Equilibrium and Kinetic studies. Indian Journal of Chemical Technology. 16(2009) $471-479$.

[65] Swamy J, Ramsay JA. The evaluation of white rot fungi in the decoloration of textile dyes. Enzyme and Microbial Technology. 24(1999)130 - 137.

[66] Tahir H, Muhammad Sultan, QaziJahanzeb. Removal of basic dye methylene blue by using bioadsorbentsUlva lactucaand Sargassum. African Journal of Biotechnology. 7 (2008)2649 2655.

[67] Wang SA. Comparative study of Fenton and Fenton-like reaction kinetics in decolourisation of wastewater. Dyes and Pigments. 76(2008) 714-720

[68] Wu J, Doan H, Upreti S. Decolorization of aqueous textile reactive dye by ozone. Chemical Engineering Journal. 142(2008)156-160

[69] Yi Liu, Zheng Y, Wang A. Enhanced adsorption of Methylene Blue from Aqueous solution by Chtosan $-\mathrm{g}-$ poly (acrylic acid)/ Vermiculite hydrogel composites. Journal of Environmental Sciences. 22(2010) 486 - 493. 